\title{
Building Knowledge Management Through the Tacit Knowledge Video
}

\author{
Aniek Juliarini' ${ }^{1}$, Jamila Lestyowati² \\ ${ }^{1,2}$ Balai Diklat Keuangan, Yogyakarta \\ ${ }^{1}$ aniek.juliarini@kemenkeu.go.id, ${ }^{2}$ jlestyowati@kemenkeu.go.id
}

\begin{abstract}
One of the things done in the knowledge management is making tacit knowledge videos. This study aims to: (1) analyze the process of tacit knowledge video production; (2) analyze the obstacles faced in making tacit knowledge videos; (3) find a solution to the obstacles encountered in making video tacit knowledge. The method used is the action research method where the authors conducted this research themselves, and then analyzed in a descriptive qualitative manner. The study uses primary and secondary data in the form of processes and experiences conducted by researchers, literature study, and video searching on Kemenkeu Learning Center (KLC). The results showed that the making of video through a series of processes, which are pre-production, production, post-production, evaluation, and uploading on KLC. The obstacle of making videos is because there is no clarity of the deadline for completing the work in the quality control stage and the lack of Widyaiswara's ability to make videos. The results of this action research can be copied by other parties who will do similar research. Another important finding from this research is the need for employees with special expertise in the video making.
\end{abstract}

Keywords:

tacit knowledge, MoF CorpU, Skill Group Owner, knowledge video

Article Received: 18 October 2020, Revised: 3 November 2020, Accepted: 24 December 2020

\section{INTRODUCTION}

General Motors started the Corpu concept in 1927 as GM Institute, and today 2400 Corpus emerged (Ayuningtias et al., 2015). In Indonesia the term "corporate university" first appeared in 2012 when several multinational companies such as PT Telkom Indonesia, PT Pertamina, and PT PLN have already implemented it (Ayuningtias et al., 2015). Meanwhile the first government institution to implement a corporate university was the Ministry of Finance, which was named the Ministry of Finance Corporate University (MoF CorpU). After all, corporate universities do not exist as standalone entities, but emerged as part of the parent organization, whose strategy inspires its mission (Cappiello \& Pedrini, 2017). Referring to the Decree of the Minister of Finance No. 924/KMK.011/2018, the Ministry of Finance CorpU is a strategy to implement the development of human resource competencies as part of achieving the vision and mission of the Ministry of Finance through the realization of the relation and appropriateness among education, learning, and the value application of values with performance targets, which is supported by knowledge management (Ministry of Finance, 2018).

Corporate University is not only a special educational or training setting, but it can also be considered as a means of managing knowledge possessed by an organization (Scarso, 2017). Decree of the Head of FETA Number KEP140/PP/2017 about the Blueprint of the Ministry of Finance Corporate University (MoF Corpu) said that one of the important pillars in the implementation of the corpu is knowledge management. Knowledge management is a system that helps people in an organization to share, access, and update knowledge and information. Knowledge is considered as an asset that helps the performance of individuals and organizations to achieve the expected goals (Mohajan, 2017).

Some Corpus are primarily intended for collection, dissemination and transfer of existing knowledge, so the aim is only to provide unskilled people specific knowledge elements that has been developed (Scarso, 2017). Knowledge and skills that are specifically possessed by an employee or an organizational unit can be a reference and learning resource for other employees or other 
organizational units. This requires a method that collaborates experience, skills, facts, relationships, values, and thoughts. If it is covered in a knowledge management, it can reduce costs, produce efficiency and being an innovative product (Mohajan, 2016). Nowadays knowledge management is valuable not only for individuals and organizations, but also for global humanity. So, knowledge should be developed to achieve competitive advantage (3).

Chen et al.(2019) found that knowledge management function of a corporate university includes knowledge transfer, knowledge creation and knowledge services for intrapreneurship. The knowledge management function of corporate universities is increasing with the development of corporate universities. Iqbal et al.(2019) say that knowledge management enabler had a significant effect on the KM process and KM process affects organizational performance directly and indirectly through innovation and intellectual capital.

Project learning is a function of the individual's internal cognitive processes, the interpretation and integration of learning at the team and project level, and the ability of the organization to institutionalize learning into practice (Wiewiora et al., 2020). They found that Project Managers, senior leaders and the project management office are involved differently in the learning process, depending on their level of connectivity and strength in the global organization. Workers who are committed to the organization are more likely to engage in $\mathrm{KS}$ behavior. Strong social ties and organizational culture play an important role in the willingness to share knowledge (Borges et al., 2019).

Knowledge sharing is a good way to share knowledge among employees of an organization. Castellani et al., 2019) concluded that good knowledge sharing intentions despite low organizational investment in knowledge sharing tools, lack of time for training and low involvement of team members in strategic objectives. Top management's knowledge value and knowledge creation practices influence open innovation, which, in turn, affects organizational performance (Singh et al., n.d.). Significant association exists between various items of intellectual capital and strategic management of knowledge and competency (Hadiati et al., 2019). It likes findings of Falah \& Prasetyo (2017), Samsiah et al.(2018), Ekawati \& Puspitowati (2016)), and Afnan \& Silvianita (2018)) state that knowledge management has a significant influence on the performance of the company. In the case of flow from tacit knowledge to knowledge socialization is very depends in willingness of individuals to share their knowledge. R\&D organization must be established KM system to capture and integrate knowledge of the individual and store it in a storage system that can be accessed by others the employees (Helmi, 2020).

One of the goals to be achieved through the Ministry of Finance of the Corpu is the realization of the Ministry of Finance as organizational learning. One of the things done in the management of the regulation in the Ministry of Finance of the CorpU is by making tacit knowledge videos. This video was made by the experience, knowledge and skills of employees in the Ministry of Finance in doing their work, which is very beneficial for the organization which is not merely owned by employees or other office units. This can be a best practice and learning resource for employees or other office units. In this research two video tacit knowledge packages are made, one problem related tp Taxpayer Identification Number (TIN), that is video " Supervision of Tax Invoice Using TIN with 000 Code". This supervision has been done by the Regional Office of the Directorate General of Taxation of the Special Region of Yogyakarta since 2017 and has given very good results, even appreciated by the Central Office of the Directorate General of Taxes. Videos are made in series from 1 to 3 . The second is a problem associated with Proxy of Budget User (PBU) with video "Being a PBU, Who's Afraid?" divided in Sections 1 and 2. According to the experiences in 
this job area it is necessary that these best practices are documented and shared so that they can be utilized or become a benchmark for stakeholders throughout Indonesia.

The formulation of the problems in this study are: 1) how the process of producing tacit knowledge videos on BDK Yogyakarta until it is uploaded on the Ministry of Finance Learning (KLC) page; 2) analyzing the obstacles faced in making video tacit knowledge; 3) finding solutions towards obstacles faced in making tacit knowledge videos.

\section{LITERATUE REVIEW}

\subsection{Corporate University}

Corporate University is a learning organisation. Learning organizations are organizations that are skilled in creating, obtaining, interpreting, transferring and maintaining knowledge and are able to change behavior, work methods, business processes, and strategies as a reflection of the level and capacity of new knowledge and insights (Garvin, 2000). Many companies around the world invest directly in higher education units, such as corporate universities. Therefore, many companies have established universities. Corporate universities may be the neutral place between present and future worlds (Cappiello \& Pedrini, 2017).

The conceptual framework for CU should be able to capture key differences between the two skill formation entities (Wang et al., 2010). They purpose an alternative functional model for capturing $\mathrm{CU}$ uniqueness like in Figure 1. It shows that, two categories of functions (skill capacity building and affiliated function) can be observed in $\mathrm{CU}$ operations.

Figure 1. A Functional Model for Corporate Universities

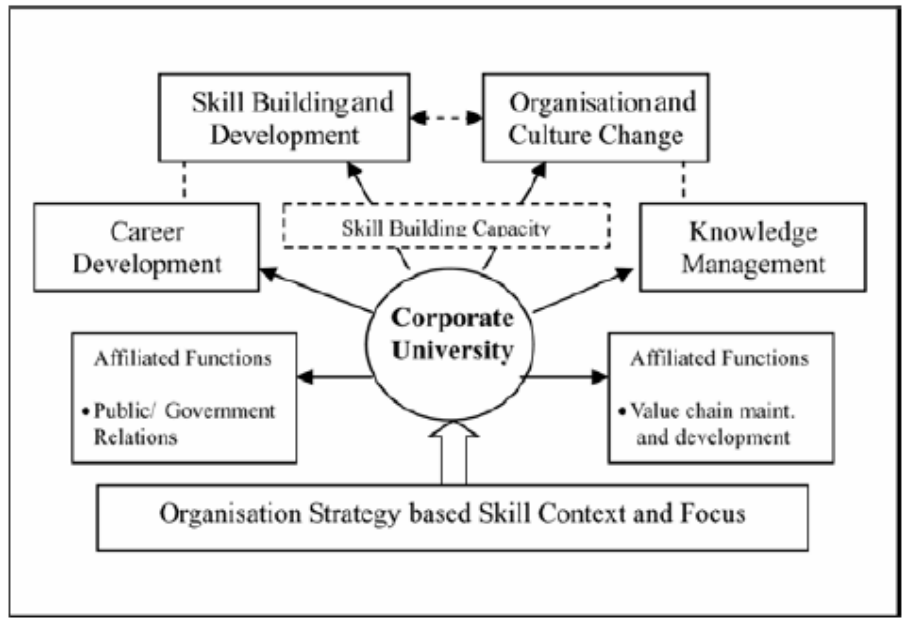

Source: Wang, et.all (2010)

The potential coverage of a corporate university is very broad. In particular, apart from providing training programs for major companies, a corporate university can be involved, either in whole or in part, in talent recruitment, change management, career paths, geographic mobility, job rotation, on-the-job training (such as mentoring and coaching), relations with conventional universities and other educational institutions (Cappiello \& Pedrini, 2017). Corporate universities do not exist as standalone entities, at least in their foundations. Corporate universities emerged as part of (and provided services to) parent organizations, whose strategies inspired its mission (Cappiello \& Pedrini, 2017), aline with Ewer \& Eft, 2017), that CU occupies a distinct, largely autonomous, positioning within the organization. In his research, Ewer found that about 40 company leaders, who hold roles as Officer, Head of Department, Division Manager, Sales Manager, and Branch Manager volunteered to teach at $\mathrm{CU}$ on a part-time schedule. Only the learning organizations are able to cope with the changes that are sure to come. The characteristics 
of learning organizations are as follows: they always offer new opportunities for learning; using the learning process to achieve its goals; find the relationship between individual performance and organizational performance; encourage dialogue and create a special environment where people express their opinions and take risks; using creative tension as a source of renewable energy; aware of its relationship with the environment in which the activity takes place (Bordeianu, 2015).

\subsection{Knowledge Management}

Managing organizational knowledge and employee competencies was observed as the key to success. However, the importance of intellectual capital for the strategic management of organizational knowledge and competence has received limited attention in the literature (Hadiati et al., 2019). Nowadays knowledge management is valuable not only for individuals and organizations, but also for global humanity. So, knowledge should be developed to achieve competitive advantage (Mohajan, 2017).

One of the main objectives of knowledge management is to utilize company knowledge (Nurmoslim, 2018). Knowledge management basically appears to answer the question of how to manage knowledge (Afnan \& Silvianita, 2018). While Ekawati \& Puspitowati,(2016) states that knowledge management is the process and mechanism of obtaining intellectual assets and other information, then disseminated within the organization to provide a competitive advantage. Knowledge management must identify organizational processes that achieve a synergistic combination of information technology data processing capacity and human capacity to create and innovate (Bordeianu, 2015).

Acceptance of knowledge and absorption of knowledge play an important role in influencing innovation (Hussein et al., 2019). There are many approaches related to $\mathrm{KM}$, but it can say that $\mathrm{KM}$ enables organizations to maximize their profits and generate value from intellectual and knowledge based assets (Bordeianu, 2015). The application of knowledge management is mainly divided into two types which are tacit and explicit (Mohajan, 2016). One of the things that can be avoided by the Corpu is to eliminate the potential lost of tacit knowledge. At the Ministry of Finance, Knowledge Management is defined as a structured and systematic effort to develop and use the knowledge it has to help the decision making process for improving organizational performance. Activities in knowledge management include efforts in acquiring, saving, process and retrieving, using and disseminating, as well as evaluating and completing knowledge as an intellectual asset of the organization. (Decree of the Minister of Finance of the Republic of Indonesia Number 924/KMK.011/2018, 2018).

Nurmoslim, 2018) suggests five reasons why knowledge management is needed, which are:

1. accelerate access to information and knowledge. Knowledge management makes it easy to find information or people who hold the information needed. This increases efficiency and productivity and allows employees to work better;

2. improve the decision making process. Employees can improve the quality and speed of decision making by accessing knowledge throughout the organization when they need it;

3. create innovation and change. Urge employees and encourage sharing of ideas, collaborate, and access to the latest information. Knowledge management makes individuals stimulating innovation and change needed to develop organizations and meet ever-changing business needs;

4. improve the efficiency of each unit of operations and business processes of the organization. With faster access to information and resources throughout the organization, workers can act quickly;

5. increase customer satisfaction. Sharing knowledge and cross collaboration helps increase the value offered to customers. The organization is able to give answers faster or 
shorten the time needed to improve the product or service. (Nurmoslim, 2018).

The application of knowledge management will affect the performance of the organization (Nurmoslim, 2018). Gartner (2014) concluded that increasing access to contextual knowledge by an employee or client reduces the time needed so as to increase customer satisfaction by $20 \%-80 \%$. A company can also reduce customer prices by $25 \%$ or more, when using appropriate knowledge management activities (Nurmoslim, 2018). Ullah et al.(2019) says knowledge management and market orientation to be the current terms because of their importance to improve organizational performance. Innovation has become the strategic needs of organizations today so that they can classify critical market competition. The world phenomenon shows that if knowledge management, market orientation and innovation in terms of performance are practiced, then the results will be very constructive (Ullah et al., 2019).

The current implementation of the CorpU Ministry of Finance has done well, but there are challenges as well. Strategic issues that still need attention are the commitment and synergy of all echelon I units related to the products and services of the Ministry of Finance Corporate University such as knowledge management and measurement of competency gap index (CGI) which requires the establishment of Technical Competency Standards that are generally applicable within the Ministry of Finance (Ministry of Finance, 2018).

\subsection{Learning Video}

Knowledge is an effective instrument that enables improvement capacity to assist companies in managing various processes (Wu et al., 2019). When organizations develop very fast, information technology and information capital are key aspects in it. KM is important because knowledge is one of the strategic weapons that strengthen a company's competitive position (Bordeianu, 2015). Since KM contains a variety of features and evolving data, it is dependent on this about implementing an IT-enabled process for collecting data every process on time (Wu et al., 2019).

The audio-visual production process can be divided into three stages, which are the stages of preproduction, production, and post-production. At the preproduction stage, the process starts from creating video concepts (drama, comedy, musical, or documentary types), looking for video references, making scripts, making storyboards, and preparing the equipment needed. Furthermore, the production stage is done by taking pictures with shooting techniques based on the concept (Sudarsana et al, 2019). Shooting process should highlight the purpose of making the video. The easiest technique can be done by wide, medium and close shooting. Director is very important in directing the style of actor and images needed. Finally, the post-production stage, there is the editing process that can be done with an online system or an offline system (https://agate.id/, 2018) .

The form of documentation of knowledge itself can actually be in the form of audio media, visual media, and audiovisual media. Audiovisual media is media which message content is received through the senses of hearing and vision. Types of audiovisual media could be but not limited to silent audiovisual media (sound frame films or sound slides). This is the media that display sound and motionless images, and can be in the form of audiovisual motion media (sound film or video), which is media that displays sound and motion pictures. Specifically, for documentation with audio visual media, FETA applies the following technical standards.

The audio quality should be in no disruption (noise, peaking/clipping (volume is too loud which results in losing the sound), puffing, and popping (distance of vocal taking that is too close to the sound source which results in small bursts));

1. Good image quality (no flicker, focus, not shaky, and great lighting (not too dark/too bright)); 
2. Volume (the speaker) is heard clearly. The background sound does not cover/disturb the voice of the speaker;

3. The maximum duration is 10 minutes, if it is more it can be divided into several parts/ series;

4. Maximum video resolution is $720 \mathrm{p}$ (HD), maximum Bitrate is 1000;

5. Video display ratio 16: 9;

6. Maximum file size of $150 \mathrm{MB}$; and

7. MP4 format.

Not all videos made are freely accessible. Regarding the level of video security, based on Article 21 of the Minister of Finance Regulation No. 226/PMK.011/2019 regarding Knowledge Management in the Ministry of Finance, it is regulated that the security level of a video is divided into four levels. Intellectual Asset access levels consist of:

1. Level 1 (secret), i.e. if the security level of Intellectual Assets can only be distributed/ disseminated to certain individuals.

2. Level 2 (confidential), i.e. the security level of Intellectual Assets that can only be distributed/disseminated to the Internal High Management Unit that compiles Intellectual Assets.

3. Level 3 (shareable), which is the security level of Intellectual Assets that can only be distributed / distributed to all employees within the Ministry of Finance.

4. Level 4 (public), which is the security level of Intellectual Assets that are not included in Level 1, Level 2, and Level 3 so that they can be distributed / distributed to the whole community.

\section{RESEARCH METHOD}

This type of research is action research. According to (Notoatmodjo, 2012), action research is mainly conducted to find a basis of practical knowledge to improve a situation in a limited way. Usually this research is conducted in an ongoing situation. Research is conducted where problem solving is needed and the results are needed to improve the situation (Notoatmodjo, 2012) .

This research uses primary data and secondary data. Primary data in the form of direct experience conducted by researchers and videomaking team. Secondary data in the form of data from klc.kemenkeu.go.id, related regulations, and literature sources including articles, books and research related to the theme. Qualitative analysis is based on the results of researchers' direct experience in making video tacit knowledge, and secondary data as a support to answer the research objectives.

\section{RESULTS AND DISCUSSION}

Knowledge management is the process and mechanism of obtaining intellectual assets and other information, then disseminated within the organization to provide a competitive advantage (Ekawati \& Puspitowati, 2016). In the implementation of making tacit knowledge videos, widyaiswara is the owner of the topic initiation, the BDK Yogyakarta Evaluation and Information Section as a supporting unit, and the Center for Education and Training as a quality controller before the video is uploaded to $\mathrm{MoF}$ Learning Centre at klc.kemenkeu.go.id. To get maximum knowledge management, manage organizational knowledge is not enough, but to develop knowledge that is owned by every individual who is in the organization (Falah \& Prasetyo, 2017). In this study, researchers as lecturer initiated the creation of two tacit knowledge video packages as follows.

1. Video Series "Supervision of Tax Invoice with TIP 000" consisting of 3 videos, which are:

a. Series I: The Other Side of Using Tax Invoice Reality with TIP 000;

b. Series II: Various Potential Taxes on Tax Invoice with TIP 000;

c. Series III: Supervision of the Use of Tax Invoice with TIP 000.

2. The video "Being PBU, Who's Afraid?", Consists of two series, which are: 
a. Being a PBU, Who's Afraid? Series I

b. Being a PBU, Who's Afraid? Series II

These topics were obtained in the process of researchers interacting with the Skill Group Owner (SGO) so that a tacit knowledge was captured that was worth documenting. Knowledge is considered as an asset that helps the performance of individuals and organizations to achieve the expected goals (Mohajan, 2017). The making of tacit knowledge videos starts from the pre-production, production, and post-production stages (https://agate.id/, 2018) .

\section{a. Pre-production}

Pre-production activity begins with the proposal preparation (Terms of Reference (TOR)). The proposal stated that the Video Series "Supervision of Tax Invoice with TIP 000" was motivated by the success of the Regional Office of the DJP DIY in finding a significant tax potential on transactions that use tax invoices with TIP 000. Through supervision of this tax invoice, the tax potential can be developed towards tax extensification, tax potential excavating, even towards tax investigations, and providing information and data to other tax offices. This quite detailed activity and created many opportunities for tax optimization has been conducted by the Regional Office of DJP DIY since 2017, in which at that time this activity had not been applied by other offices so that it was appreciated by the DJP Head Office. Therefore, this knowledge, skills and experience are worth documenting.

Acting as the speaker or experts (SME) are Mr. Dionysius Lucas Hendrawan (Head of Regional Office of the DJP DIY) on video 1, Mr. Fajar Adi Prabawa (Head of Inspection, Billing, Intelligence, and Investigation ) on video 2, and Mr. Rudi Saptono (Civil Servant Investigator) on video 3. With this tacit knowledge video, it is expected that the knowledge and experience of the SMEs can be documented and disseminated, among others, through KM in the KLC so that it could be a trigger or guide for other offices to do the same thing. The video was taken with guided free interviews concept. In this interview, the interviewer has prepared a number of important questions, and has been communicated in advance with the interviewee before the shooting begins. In this way the interview becomes directed and the interviewee is having a better preparation to answer questions, and more focused so that the shooting time is more efficient. Considering that the tacit knowledge video is determined to only have around 10 minutes long, this would be very important to be noted (Peraturan Menteri Keuangan Nomor 226/PMK.0II/2019, 2019, p. 226).

Video "Being PBU, Who's Afraid?" is motivated by the large number of PBU which in this case, mostly held by the head of the office who do not understand the work business processes, duties and functions. Therefore, many concerns arise when doing their duties because they do not yet know exactly what their authority and position as financial managers are. Therefore, there needs to be a PBU figure who is successful in doing his duties as a PBU to inspire other PBU fellow. Based on their abilities and achievements, Ms. Herlin Sulismiyarti (Head of KPP Pratama Wates) and Mr. Endaryono (Head of KPP Jepara) were determined to become SMEs as tacit knowledge owners to share experiences with other PBUs through this video.

After the speaker and topic are determined, a TOR is made which is equipped with a video concept, goals, time line, storyboard, script, and the person in charge of the activity, which is widyaiswara. Then, by BDK Yogyakarta Evaluation and Information Officer, the TOR is sent to the Education and Training Center in charge of competencies / material related to video content for evaluation and approval. The TOR video series "Oversight of Tax Invoice with TIP 000" is sent to the Tax Training Center in Jakarta, while the TOR video "Becomes PBU, Who's Afraid?" sent to the Budget and Treasury Training Center, in Bogor. Furthermore, TOR will be evaluated by the related Education and Training Center. In its implementation, the period of 
validation and TOR approval varies from one education center to another. This is what causes the process of making videos sometimes not in accordance with the plan. The results of the validation itself can be in the form of an agreement to directly make the video, a partial revision or a total revision by changing the video theme. After TOR validation is received and approved, the next process is the video production stage.

\section{b. Production}

In making knowledge management videos, BDK Yogyakarta has a KM Team responsible in assisting the process of video production and postproduction. However, due to team members' routine work, it was difficult for this team to find time to do recording and editing activities. This has become one of the obstacles and challenges in making learning videos. Another way that can be done is to make videos independently by widyaiswara, or made with the help of training students, internship students, or even with the public relations team at the SGO office. The process of shooting the video "Supervision of Tax Invoice with TIP 000" was done by the public relations team of DJP DIY Regional Office, while the video "Being PBU, Who's Afraid?" conducted by the KM BDK Yogyakarta Team.

BDK Yogyakarta already has sufficient equipment such as good quality camera, tripod, rig, lense, filter, lighting, audio, laptop/computer, editing software, and studio space that can be used for shooting and editing. To use this equipments, a skilled person is needed. Shooting can be done in the studio or in the BDK Yogyakarta area such as in the library, dining room, classroom, hall, in the park, or even taking awesome locations outside the BDK Yogyakarta office or the office of the speaker to make it easier to do. The output of the production process is an mp4 file that contains pictures and sounds and mp3 files that only contain sound recordings.

For documentation with audio visual media, FETA applies the following technical standards (Keputusan Kepala BPPK Nomor KEP118/PP/2019, 2019).

1) The audio quality should be in no disruption (noise, peaking/clipping (volume is too loud which results in losing the sound), puffing, and popping (distance of vocal taking that is too close to the sound source which results in small bursts);

2) Good image quality (no flicker, focus, not shaky, and great lighting (not too dark/too bright);

3) Volume (the speaker) is heard clearly. The background sound does not cover / disturb the voice of the speaker;

4) The maximum duration is 10 minutes, if it is more it can be divided into several parts/series;

5) Maximum video resolution is 720p (HD), maximum Bitrate is 1000 ;

6) Video display ratio 16: 9;

7) Maximum file size of $150 \mathrm{MB}$; and

8) MP4 format.

\section{c. Postproduction}

Postproduction activities is done by editing the results of shooting and sound recording. Editing requires a long time because it requires patience, accuracy, and discipline. Good editing techniques will produce good quality videos, both in images, sound, visuals and others. However, it is possible after finishing editing, new content needs to be added, so that it is necessary to take a video again or take pictures / videos from other places. This will make video completion process longer. There is various editing process time itself, it can be in a couple of hours but it can also take days or even weeks because this work is done on the routine office work time. Moreover, video making work is not the target of activities (Key Performance Indicators) for the KM team.

The video file that has been made, then submitted by the Evaluation and Information Section to the relevant Education Center for validation and approval to be posted on KLC. The video validation process by the education center 
requires an uncertain time, because there is no regulation on that as the time for the approval of the TOR that has not been set by the FETA. This is a challenge and obstacle because there is no certainty when the validation results can be received. The results of the validation can be a revision so that the video is repaired, added content, or reduced content. Validation can be on the substance of the video material or on the editing techniques, such as sound quality, back song, image quality, and so on. If there are validation results that require further improvement, then the video should be corrected according to the validator's recommendations.

Not all videos made are freely accessible. The security level of a video is divided into four levels (12).

1) Level 1 (secret), i.e. if the security level of Intellectual Assets can only be distributed / disseminated to certain individuals.
2) Level 2 (confidential), i.e. the security level of Intellectual Assets that can only be distributed / disseminated to the Internal High Management Unit that compiles Intellectual Assets.

3) Level 3 (shareable), which is the security level of Intellectual Assets that can only be distributed / distributed to all employees within the Ministry of Finance.

4) Level 4 (public), which is the security level of Intellectual Assets that are not included in Level 1, Level 2, and Level 3 so that they can be distributed / distributed to the whole community.

The Training Center and FETA will also determine the security level of a video whether it is in level 1,2, 3 or 4 . The final result of the video that has been validated, is a video that is ready to be launched at klc.kemekeu.go.id. and/or youtube of FETA.

\section{The results obtained}

a. "Supervision of Tax Invoice with TIP 000" video series

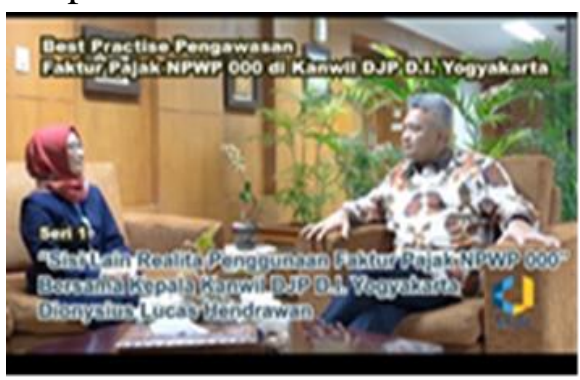

Seri 1

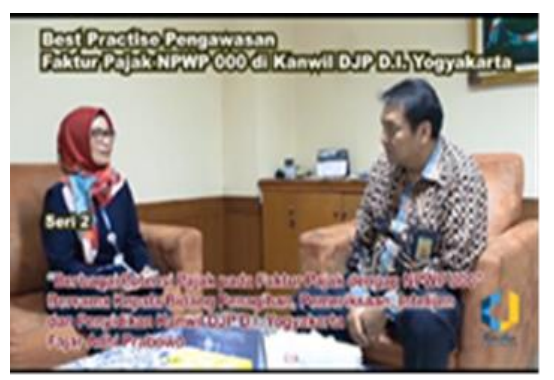

Seri 2

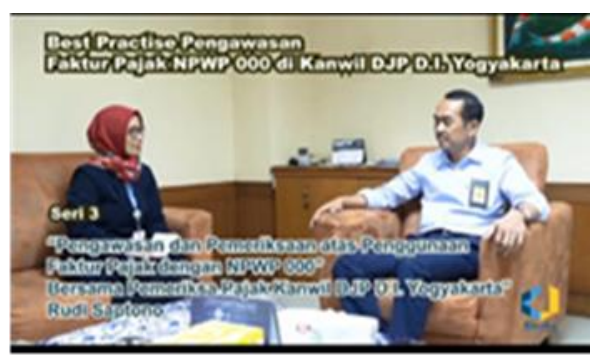

Seri 3 
b. "Being PBU, Who's Afraid?" video series.

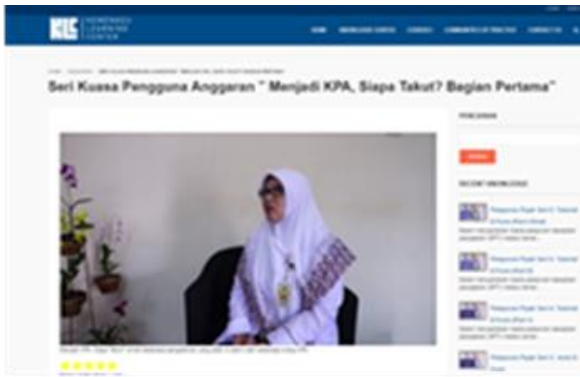

Seri 1

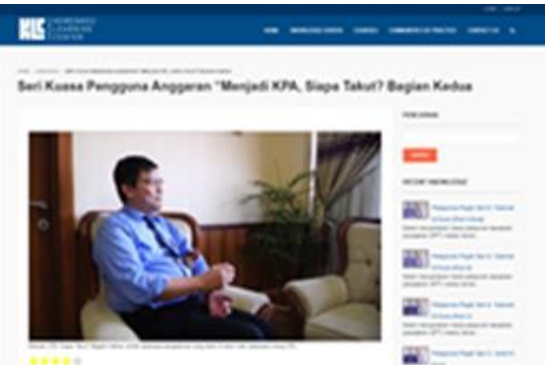

Seri 2

\section{Obstacles encountered}

The completion of tacit knowledge video faces several obstacles, including:

a. Validation of video proposals for which there is no time limit. This results in a video that cannot be produced according to plan because of the slow validation results;

b. The period of validation of the final video has not been set. This results in the process of displaying videos on KLC could be delayed.

c. The KM Team is not optimal because making videos is not a main job and function, while widyaiswara (as the owner of ideas), in this matter, not all of them have the competence to make good videos.

\section{Solutions to the obstacles encountered}

Based on the obstacles faced, the solutions that can be done are:

a. There should be a clear rule regarding the period of TOR and video validation by the Education and Training Center before showing the video on KLC.

b. Increased widyaiswara's competence in the practical way of making videos through knowledge sharing by experts.

c. There are functional employees of Learning Technology Developers whose special task is to make learning material in the form of audio or audio visual.

\section{CONCLUSIONS}

The Ministry of Finance CorpU is a strategy to implement the development of human resource competencies as part of achieving the vision and mission of the Ministry of Finance through the realization of the relation and appropriateness among education, learning, and the value application of values with performance targets, which is supported by knowledge management. Knowledge management is an important process of obtaining intellectual assets and other information, like tacit knowledge, then disseminated within the organization to provide a competitive advantage.

One of the things done in knowledge management is to create a tacit knowledge video that would be best practice and a source of learning for employees or other offices so it can improve organizational performance. Documentation of tacit knowledge in the form of audio-visual (video) will be able to transfer material more attractively and is well liked by today's millennial generation, easily and quickly to be accessed. In MoF Corpu in Indonesia, the security level of a video is divided into four levels, that are Level 1 is secret, Level 2 is convidential, Level 3 is shareable, and Level 4 is Public.

In making $\mathrm{KM}$ videos, the process that was passed was Preproduction, Production, and Postproduction. Preproduction process includes the selection of themes, the determination of the speaker, the method of taking pictures, the time of implementation, and the teams involved, all of which are written in the Terms of Reference. Production process is the stage of shooting, it can be done by the video maker, or an internal team or the SGO team. Postproduction process includes 
editing stage to meet technical requirements such as sound quality, image quality, video duration, and so on. The video that has been made is checked first for its quality (quality control) by the Education and Training Center in charge of video material content and the level of security. Finally the video is ready to be uploaded to KLC and Youtube, and can be used by trainees, all employees, or the wider community. Obstacles faced are unclear time for TOR approval and video validation, as well as widyaiswara's technical skills in video making. To produce quality videos, a functional Learning Technology Developer employee is needed.

\section{REFERENCES}

[1] Afnan, E., \& Silvianita, A. (2018). Pengaruh Knowledge Management Process Terhadap Kinerja Karyawan (Studi pada Divisi Big Data PT Telkom Indonesia). E-Proceeding of Management, 5(3), 3888.

[2] Ayuningtias, Anggadwita, Nurbaeti, \& Putri. (2015). The Corporate University Landscape in Indonesia. 3rd International Seminar and Conference on Learning Organization (ISCLO 2015), 0200.

[3] Keputusan Kepala BPPK Nomor KEP118/PP/2019, (2019).

[4] Bordeianu, O. (2015). The Role of Knowledge Management and Knowledge Management Strategies Within Learning Organizations. ECOFORUM, 4(1 (6)).

[5] Borges, R., Bernardi, M., \& Petrin, R. (2019). Cross-country findings on tacit knowledge sharing: Evidence from the Brazilian and Indonesian IT workers. Journal of Knowledge Management, 23(4), 742-762. https://doi.org/10.1108/JKM-04-2018-0234

[6] Cappiello, G., \& Pedrini, G. (2017). The performance evaluation of corporate universities. https://doi.org/DOI: 10.1080/13583883.2017.1329452

[7] Castellani, P., Rossato, C., Giaretta, E., \& Davide, R. (2019). Tacit knowledge sharing in knowledge-intensive firms: The perceptions of team members and team leaders. Review of Managerial Science, Tacit knowledge sharing in knowledge-intensive firms: the perceptions of team members and team leaders. https://doi.org/10.1007/s11846019-00368-x

[8] Chen, Y., Xu, Y., \& Zhai, Q. (2019). The knowledge management functions of corporate university and their evolution: Case studies of two Chinese corporate universities. Journal of Knowledge Management, Vol. 23 No. 10, Pp. 2086-2112., 23(10), 2086-2112. https://doi.org/10.1108/JKM-04-2018-0228

[9] Ekawati, S., \& Puspitowati, I. (2016). Pengaruh Manajemen Pengetahuan Dan Inovasi Terhadap Kinerja Perusahaan UKM di Jakarta. Conference on Management and Behavioral Studies Universitas Tarumanagara, Jakarta.

[10] Ewer, G., \& Eft, D. (2017). Corporate University Theory and Practice: The Case of Platt University, USA. International Journal of HRD Practice, Policy and Research, 2(1), 35-49. https://doi.org/doi: 10.22324/ijhrdppr.2.104

[11] Falah, A. S. N., \& Prasetyo, A. (2017). Pengaruh Knowledge Management Terhadap Kinerja Karyawan dan Kinerja Perusahaan (Studi pada Karyawan PT Semen Indonesia Persero Tbk). Jurnal Administrasi Bisnis (JAB), 50(40), 192-198.

[12] Garvin, D. (2000). Learning in Action: A Guide to Putting the Learning Organization to Work. Harvard Business School Press.

[13] Hadiati, F., Tyaz, N., Yusro, H., \& Christianus, M. (2019). Strategic management of organizational knowledge and competency through intellectual capital. 19(2), 132-141. https://doi.org/10.17512/pjms.2019.19.2.11

[14] Helmi, R. (2020). Knowledge Management Enabler (KME) to Promote Innovation Capabilities in Public R\&D Centers in Indonesia. The Asian Journal of Technology Management, 13(2), 98--112. 
[15] https://agate.id/. (2018). Corporate University Boom in Indonesia What is Corporate University? https://agate.id/corpuindonesian-boom/

[16] Hole, Y., \& Snehal, P. \& Bhaskar, M. (2018). Service marketing and quality strategies.

a. Periodicals of engineering and natural sciences, 6 (1), 182-196.

[17] Hole, Y., \& Snehal, P. \& Bhaskar, M. (2019). Porter's five forces model: gives you a

a. advantage. Journal of Advanced Research in Dynamical and Control

b. System, 11 (4), 1436-1448.

[18] Hussein, A., Rosita, N., \& Ayuni, R. (2019). Knowledge Management Orientation Behaviour and Innovation: A Lesson From Indonesia Creative Economy Sector. International Journal of Sociotechnology and Knowledge Development (IJSKD), 11(1), 12. https://doi.org/DOI:

10.4018/IJSKD.2019010102

[19] Iqbal, A., Latif, F., Marimon, F., Sahibzada, U. F., \& Hussain, S. (2019). From knowledge management to organizational performance: Modelling the mediating role of innovation and intellectual capital in higher education. Journal of Enterprise Information Management, 32(1), 36-59. https://doi.org/10.1108/JEIM-04-2018-0083

[20] Ministry of Finance, C. T. O. (2018). Transformasi Untuk Indonesia Yang Lebih Baik, LAPORAN TAHUNAN Program Reformasi Birokrasi dan Transformasi Kelembagaan Kementerian Keuangan Tahun 2018. Ministry of Finance o Republic of Indonesia.

[21] Mohajan, H. (2016). Sharing of Tacit Knowledge in Organizations: A Review. American Journal of Computer Science and Engineering, 3, 6-19.

[22] Mohajan, H. (2017). Tacit Knowledge for the Development of Organizations. ABC Journal of Advanced Research, Volume 6, No 1(2017), 17-24.
[23] Notoatmodjo, S. (2012). Metodologi Penelitian Kesehatan (2nd ed.). PT Rineka Cipta.

[24] Nurmoslim. (2018). 5 ALasan Kenapa Knowledge Management Diperlukan. https://sis.binus.ac.id/. https://sis.binus.ac.id/2018/01/26/5-alasankenapa-knowledge-management-diperlukan/

[25] Peraturan Menteri Keuangan Nomor 226/PMK.0II/2019, (2019).

[26] Samsiah, S., Marlina, E., \& Ardi, H. A. (2018). Pengaruh Knowledge Management Dan Teknologi Informasi Terhadap Keunggulan Bersaing Dan Kinerja Universitas. Jurnal Manajemen Universitas Muhammadiyah Riau, XXII(02), 154-167.

[27] Scarso, E. (2017). Corporate universities as knowledge management tools. VINE Journal of Information and Knowledge Management Systems, 47(4), 538--554. https://doi.org/10.1108/VJIKMS-12-20160074

[28] Singh, K., Gupta, K., Busso, D., \& Kamboj, S. (n.d.). Top management knowledge value, knowledge sharing practises, open inovation and organizational peformance. Journal of Business Research. https://doi.org/10.1016/j.jbusres.2019.04.040

[29] Sudarsana, I. K., Putra, I. P. A. W., Anam, F., Istianti, T., Pandin, M. G. R., Bhawika, G. W., ... \& Laili, N. R. (2019, November). The Function Of Technology And Device Laptop For Education Purpose. In Journal of Physics: Conference Series (Vol. 1363, No. 1, p. 012062). IOP Publishing.

[30] Ullah, I., Mirza, B., Abbas, F., \& Kashif, A. R. (2019). Examination of knowledge management and market orientation, innovation and organizational performance: Insights from telecom sector of Pakistan. Knowledge Management \& E-Learning, 11(4), 522-551. https://doi.org/10.34105/j.kmel.2019.11.027

[31] Wang, G., Li, J., Qiao, X., \& Sun, J. (2010). Understanding the Corporate University 
phenomenon: A human capital theory perspective. International Journal of Human Resources Development and Management, 10(2), 182-204. https://doi.org/DOI: 10.1504/IJHRDM.2010.031443

[32] Wiewiora, A., Chang, A., \& Smidt, A. (2020). Individual, project, and organisational learning flows within global projectorganization: Explroring what, how, and who. International Journal of Project Management, $\quad 38(4), \quad$ 201-214. https://doi.org/10.1016/j.ijproman.2020.03.00 5

[33] Wu, K., Xiaa, Gao, Tseng, Chiud, \& Zhange. (2019). Enhancing corporate knowledge management and sustainable development: An inter-dependent hierarchical structure under linguistic preferences. Resources, Conservation \& Recycling, 146, 560-579. https://doi.org/10.1016/j.resconrec.2019.03.0 15

[34] Yogesh Hole et al 2019 J. Phys.: Conf. Ser. 1362012121 